LuUndberg, O., Cederqvist, E. \& Standnitz, W. von (1967) Medullary thyroid carcinoma and phaeochromocytoma: a familial chromaffinomatosis. British Medical Journal, 1, 279.

Parkinson, T. (1964) Phaeochromocytoma presenting as postural hypotension. Proceedings of the Royal Society of Medicine, 57, 673.

Shanks, R.G., Hadden, D.R., Lowe, D.G.C., McDevitT, D.G. \& MONTGOMERY, D.A.D. (1969) Controlled trial of propranolol in thyrotoxicosis. Lancet, i, 993.

SHERWIN, R.P. (1959) Histopathology of phaeochromocytoma. Cancer, 12, 861.

SIPPLE, J.H. (1961) The association of phaeochromocytoma with carcinoma of the thyroid gland. American Journal of Medicine, 31, 163.
Tumer, P., Granville-Grossman, K.L. \& Smart, J.V. (1965) Effect of adrenergic receptor blockade on the tachycardia of thyrotoxicosis and anxiety. Lancet, ii, 1316.

WERNER, S.C. \& INGBAR, S.H. (1971) The Thyroid, 3rd Edition, p. 496. Harper and Rowe, New York.

Williams, E.D. \& Pollock, D.J. (1966) Multiple mucosal neuromata with endocrine tumours, a syndrome allied to von Reklinghausen's disease. Journal of Pathology and Bacteriology, 91, 71.

Wiswell, J.G., HuRwitz, G.C., CoRonho, V., Bing, O.H.L. \& CHILD, D.L. (1963) Urinary catecholamines and their metabolites in hyper and hypo-thyroidism. Journal of Clinical Endocrinology, 23, 1102.

WOLLERBURGER, A. (1965) Current topics in thyroid research (Ed. by D. C. Casson and M. Andreoli), p. 377. Academic Press, Inc., New York.

\title{
Arterial surgery in pseudoxanthoma elasticum
}

\author{
D. J. CARTER \\ M.R.C.P.
}

\author{
F. P. VINCE \\ M.R.C.P.
}

\author{
D. A. K. WOODWARD \\ F.R.C.S.
}

Walsgrave Hospital, Coventry

\begin{abstract}
Summary
A 25-year-old female with pseudoxanthoma elasticum was referred with disabling ischaemia in one lower limb. She had suffered from peripheral vascular disease from the age of 15. Reconstructive arterial surgery was successful.
\end{abstract}

\section{Case report}

A 25-year-old female was referred in 1973 with a history of ulceration of the left foot for 3 months, with severe pain at rest. Walking had become too painful to attempt. Pseudoxanthoma elasticum had been diagnosed at the age of 7 on the basis of classical skin changes. She had suffered from intermittent claudication in both calves for at least 10 years. A haematemesis had occurred in 1967. She became thyrotoxic in 1972 and was treated with carbimazole. On referral in 1973 she was euthyroid. Skin changes of pseudoxanthoma elasticum were present, particularly involving the sides of the neck. Angioid streaks were seen on fundoscopy. The lower limbs were wasted. The peripheral pulses were absent below the femorals. A painful ulcer, $3 \times 2.5 \mathrm{~cm}$, was present on the dorsum of the left foot, and a smaller

Correspondence: Dr D. J. Carter, Department of Medicine, Walsgrave Hospital, Coventry CV2 2DX. ulcer was noted on the medial malleolus of the same foot. She was normotensive and an electrocardiogram was normal.

A lumbar sympathectomy was performed but there was no improvement. A left femoral arteriogram showed small calibre vessels and occlusion of the left femoral artery in its distal third. There was good filling of the popliteal artery via collaterals (Fig. 1). Femoropopliteal by-pass grafting was therefore carried out. At operation the left femoral artery was very small but patent. It was dissected free below the origin of the profunda femoris artery and a length of reversed autogenous saphenous vein was sutured, end to side, proximally to the top end of the superficial femoral artery and distally to the popliteal artery which was of wider calibre than the femoral. Both arteries took sutures normally. Postoperatively there was a return of the peripheral pulses in the left leg. Pain was relieved and the ulcer gradually healed. Twelve months later full recovery in the limb was maintained.

\section{Discussion}

Pseudoxanthoma elasticum is a genetically determined, probably autosomal recessive, disorder. A number of recent studies (Moran and Lansing, 1958; 


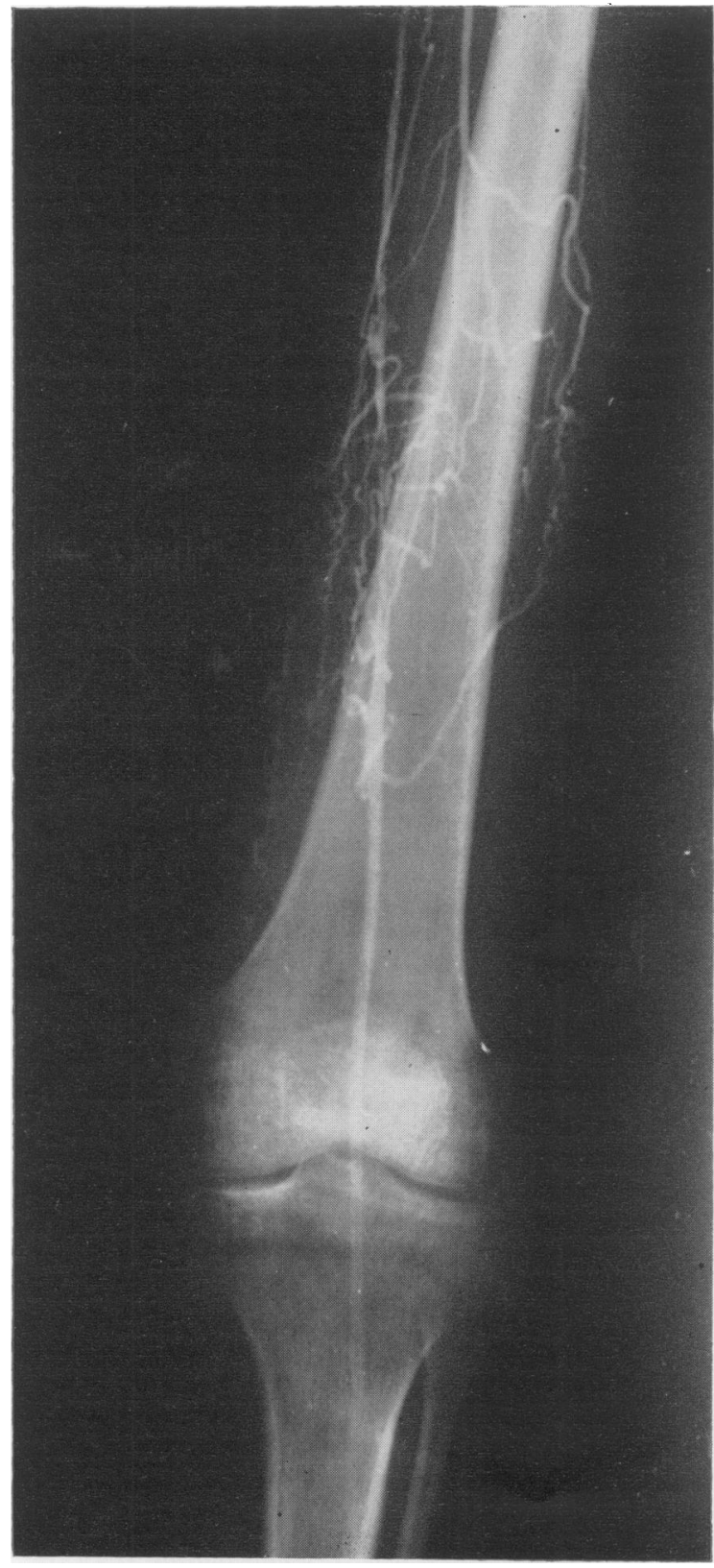

FIG. 1. Left femoral arteriogram, showing femoral occlusion and extensive collateral circulation.

Huang, Steele and Kumar, 1967) have confirmed the view proposed by Darier in 1896 that the basic defect involves elastic fibres. Deposition of calcium on elastic fibres which appear otherwise normal has been reported (Goodman et al., 1963) as the earliest detectable change in the histogenesis of pseudoxan- ̊ thoma elasticum. Its exact relationship to the genetic $>$ defect is not yet understood.

Absent or diminished peripheral pulses occur in $\subseteq$ $25 \%$ of cases of pseudoxanthoma elasticum, and $\overrightarrow{\vec{F}}$ symptoms of intermittent claudication have been $\stackrel{9}{\rightarrow}$ found in $18 \%$ (Eddy and Farber, 1962). However, severe ischaemic changes in the lower limbs are $\frac{\bar{c}}{\bar{D}}$ uncommon (Connor et al., 1961; Alinder and $\vec{\nabla}$ Boström, 1972). It is believed that the slow progress $\varrho$ of the arterial disease allows the development of $\%$ adequate collaterals. Arteriography in one study $\overrightarrow{0}$ (Carlborg et al., 1959) demonstrated arterial occlu- sive changes frequently in the lower limbs, whereas $\vec{\omega}$ others (Goodman et al., 1963) found such changes $\frac{\rho}{8}$ more prominent in the upper extremities. Calcification of peripheral arteries had been reported as early as the ninth year of life (Wolff, Stokes and Schlesin- N ger, 1952). There was no hypertension in the present 8 patient although it has been described in $22.5 \%$ of cases (Eddy and Farber, 1962).

Vascular surgery was performed in this case in an attempt to rescue a limb and relieve pain in a young and otherwise active subject. Technical difficulties $\vec{z}$ expected to be associated with the vascular disorder were not a problem. The successful outcome suggests $\overrightarrow{\vec{\theta}}$ that, in the presence of severe arterial insufficienco in pseudoxanthoma elasticum, arterial reconstrue tive surgery can provide striking benefit.

\section{References}

AlInder, I. \& BoströM, H. (1972) Clinical studies on Swedish material of pseudoxanthoma elasticum. Acta medica scandinavica, 191, 273.

Carlborg, U., EJRuP, B., Grönblad, E. \& Lund, F. (1959) Vascular studies in pseudoxanthoma elasticum and angioid streaks. Acta medica scandinavica, Suppl. 350, 1.

Connor, P.J., Juergens, J.L., Perry, H.O., Hollenhorst, R.W. \& EdWARds, J.E. (1961) Pseudoxanthoma elasticum and angioid streaks. A review of 106 cases. American Journal of Medicine, 30, 537.

DARIER, J. (1896) Pseudoxanthoma elasticum. Monatshefte für praktische Dermatologie, 23, 609.

EDDY, D. \& FARBER, E.M. (1962) Pseudoxanthoma elasticum. Internal manifestations. A report of cases and a statistical review of the literature. Archives of Dermatology, 86, 729.

Goodman, R.M., Smith, E.W., Paton, D., Bergman, R.A., Siegel, C.L., Ottesen, O.E., Shelley, W.M., Pusch, A.L. \& MCKusick, V.A. (1963) Pseudoxanthoma elasticum. A clinical and histological study. Medicine. Baltimore, 42, 29. N

HuANG, S.N., STeele, H.D. \& Kumar, G. (1967) Ultrastructural changes of elastic fibres in pseudoxanthoma $N$ elasticum. A study of histogenesis. Archives of Pathology, N 83, 108.

Moran, T.J. \& LANSING, A.I. (1958) Studies on the nature of $\underset{\gamma}{0}$ abnormal fibres in pseudoxanthoma elasticum. A.M.A. Archives of Pathology, 65, 688.

WolfF, H.H., Stokes, J. \& Schlesinger, B. (1952) Vascular abnormalities associated with pseudoxanthoma elasticum. Archives of Disease in Childhood, 27, 82. 